\title{
Dietary $\beta$-glucans and mannanoligosaccharides improve growth performance and intestinal morphology of juvenile pacu Piaractus mesopotamicus (Holmberg, 1887)
}

\author{
Hamilton Hisano $^{1}$ (D) Michelly Pereira Soares ${ }^{2}$. \\ Fabiana Golin Luiggi ${ }^{3}$. Arielle Cristina Arena ${ }^{4}$
}

Received: 17 April 2017 /Accepted: 9 October 2017 / Published online: 16 October 2017

(C) Springer International Publishing AG 2017

\begin{abstract}
The objective of this study was to evaluate the effect of increased levels $(0.0,0.1$, $0.2,0.4$, and $0.8 \%$ ) of a combination of $\beta$-glucans and mannanoligosaccharides (MOS) in isonitrogenous ( $23 \%$ of digestible protein) and isoenergetic (13.38 MJ of digestible energy $\mathrm{kg}^{-1}$ ) pacu diets, corresponding to five treatments and four replicates. A 30-day feeding trial was conducted to assess the effects on growth performance, hematological parameters, and intestinal morphology. Fish ( $n=160,30.92 \pm 0.46 \mathrm{~g})$ were distributed randomly in 20 aquaria $(300 \mathrm{~L})$ with a recirculating water system with controlled temperature $\left(26.20 \pm 0.32{ }^{\circ} \mathrm{C}\right)$ and fed four times a day until apparent satiation. A quadratic effect $(P<0.05)$ was observed for weight gain (WG), feed conversion ratio (FCR), and protein efficiency ratio (PER). The hepatosomatic and viscerosomatic indexes, hematocrit, hemoglobin, mean corpuscular volume (MCV), and mean corpuscular hemoglobin concentration (MCHC) did not show differences $(P>0.05)$ among treatments. Pacu fed $\beta$-glucans and MOS at 0.1 and $0.2 \%$ resulted in the greatest $(P<0.05)$ villus height and perimeter. The diet containing $0.2 \% \beta$-glucans and MOS promoted the best growth response, feed efficiency, and intestinal morphology, without detrimental effects on the hematological parameters for juvenile pacu.
\end{abstract}

Keywords Feed additive $\cdot$ Histology $\cdot$ Intestine $\cdot$ Polysaccharides $\cdot$ Prebiotic

Hamilton Hisano

hamilton.hisano@embrapa.br

1 Embrapa Meio Ambiente, Rodovia SP 340, Km 127,5, 13820-000, Jaguariúna, SP C.P. 69, Brazil

2 Universidade Estadual de Mato Grosso do Sul, Aquidauana, MS, Brazil

3 YesSinergy, Campinas, SP, Brazil

4 Universidade Estadual Paulista, Botucatu, SP, Brazil 


\section{Introduction}

Aquaculture has grown exponentially in the last decades. During the 2005-2014 period, fish culture production grew at 5.8\% per year (FAO 2016). Production of aquatic animals from aquaculture in 2014 was 73.8 million metric $\mathrm{t}$, and fish culture contributed 49.8 million metric $t$ to this total (FAO 2016). To meet these increasing demands for fish, aquaculture systems are becoming more intensive. However, aquaculture intensification requires high stocking densities and routine handling, subjecting aquatic species to several stress conditions, which can negatively affect the health and growth (Shrimpton et al. 2001). Thus, the use of some feed additives with immunological and growth enhancement proprieties in fish diets is important to mitigate these deleterious effects.

Feed additives originated from yeast Saccharomyces cerevisiae and its co-products such as autolyzed yeast and yeast cell wall (primarily $\beta$-glucans and mannanoligosaccharides-MOS) have been successfully evaluated in fish diets as a growth promoter for hybrid striped bass Morone chrysops $\times$ M. saxatilis (Li and Gatlin 2003), Nile tilapia Oreochromis niloticus (Hisano et al. 2007; Signor et al. 2010; Selim and Reda 2015), pacu Piaractus mesopotamicus (Watanabe et al. 2010), as well as an immunostimulant for gilthead seabream Sparus aurata (Ortuño et al. 2002), and hybrid striped bass (Li and Gatlin 2004), reducing the injuries associated to intensive management.

Commercial isolated $\beta$-glucans and/or MOS are derived from yeast cell walls. According to Hough (1990), yeast cell walls are composed of $40.0 \%$ of $\beta$-glucans, $40.0 \% \alpha$-mannans, $8.0 \%$ protein, $7.0 \%$ lipids, and $3.0 \%$ inorganic substances. In fish, $\beta$-glucans are considered an immunostimulant that act on non-specific defense mechanisms, inducing phagocytic activity of macrophages (Engstad 1993; Paulsen et al. 2001; Gopalakannan and Arul 2010), as well as the release of lysozymes, cytokines, interferons, and leukocyte migration through macrophage activation (Secombes and Fletcher 1992). MOS are glucomannoprotein complexes and has prebiotic and immunostimulant properties that can prevent (direct and indirect) colonization of pathogenic bacteria and increase the immunological status of fish by inducing intracellular signaling cascades that may enhance the production of proinflammatory cytokines (Staykov et al. 2007; Torrecillas et al. 2007; Ringø et al. 2010; Song et al. 2014).

Furthermore, MOS maintain the intestinal microbiota balance (Ringø et al. 2010; Patel and Goyal 2012), and their use isolated or in combination with $\beta$-glucans improves the intestinal morphology of the microvilli structure and absorptive surface in fish (Hisano et al. 2006; Dimitroglou et al. 2009; Schwarz et al. 2010; Selim and Reda 2015). However, few studies have been evaluated a combination of $\beta$-glucans and MOS as a supplement in fish diets (Selim and Reda 2015).

Pacu P. mesopotamicus culture is increasing in tropical and sub-tropical regions due its desirable zootechnical characteristics, such as good growth, rusticity, and meat quality, which are highly appreciated by consumers (Castagnolli and Zuim 1985). In Brazil, pacu and its hybrids were some of the main indigenous species cultured in 2015 (IBGE 2015).

Thus, this study aimed to evaluate the effects of graded levels of dietary combined $\beta$-glucans and MOS on the growth performance, hematology, and intestinal morphology of juvenile pacu. 


\section{Materials and methods}

\section{Ingredients and experimental diets}

Five isonitrogenous (23\% of digestible protein -DP) and isoenergetic (13.38 $\mathrm{MJ} \mathrm{kg}^{-1}$ digestible energy - DE) diets were formulated based on the digestible values presented by Abimorad et al. (2008) for pacu. The same level of digestible lysine, methionine, threonine, calcium, and phosphorus was maintained for all experimental diets (Table 1).

Dietary ingredients were ground in a knife mill (Marconi MA340, Piracicaba, SP, Brazil) to achieve a $0.5-\mathrm{mm}$ particle size and then weighed and mixed in a Y vertical mixer (Marconi MA201, Piracicaba, SP, Brazil), moistened with approximately $20 \%$ water and processed into 2.5-mm-diameter pellets in a laboratory pelletizer (G Paniz MCR22, Caxias do Sul, RS, Brazil). The yeast polysaccharide feed additive was primarily composed of $\beta$-1.3/1.6-glucans and MOS (Glucan-MOS ${ }^{\circledR}$ ) and was produced and provided by YesSinergy do Brasil

Table 1 Formulation, proximate and estimated composition of experimental diets (based on dry matter)

\begin{tabular}{|c|c|c|c|c|c|}
\hline \multirow[t]{2}{*}{ Ingredient } & \multicolumn{5}{|c|}{$\beta$-Glucans and MOS (\%) } \\
\hline & 0.0 & 0.1 & 0.2 & 0.4 & 0.8 \\
\hline Soybean meal & 44.70 & 44.80 & 44.80 & 44.90 & 45.00 \\
\hline Corn & 31.72 & 31.45 & 31.29 & 30.87 & 30.08 \\
\hline Wheat middlings & 17.35 & 17.35 & 17.35 & 17.35 & 17.35 \\
\hline Soybean oil & 1.60 & 1.67 & 1.73 & 1.86 & 2.15 \\
\hline Dicalcium phosphate & 3.37 & 3.37 & 3.37 & 3.37 & 3.37 \\
\hline Calcitic limestone & 0.20 & 0.20 & 0.20 & 0.20 & 0.20 \\
\hline L-Lysine $(78 \%)$ & 0.37 & 0.37 & 0.37 & 0.36 & 0.36 \\
\hline DL-Methionine (99\%) & 0.07 & 0.07 & 0.07 & 0.07 & 0.07 \\
\hline Sodium chloride $(\mathrm{NaCl})$ & 0.10 & 0.10 & 0.10 & 0.10 & 0.10 \\
\hline Glucan-MOS ${ }^{\circledR}$ & - & 0.10 & 0.20 & 0.40 & 0.80 \\
\hline Vitamin and mineral premix ${ }^{\mathrm{a}}$ & 0.50 & 0.50 & 0.50 & 0.50 & 0.50 \\
\hline Butyl hydroxy toluene & 0.02 & 0.02 & 0.02 & 0.02 & 0.02 \\
\hline \multirow[t]{2}{*}{ Total } & 100.00 & 100.00 & 100.00 & 100.00 & 100.00 \\
\hline & \multicolumn{5}{|c|}{ Proximate and estimated composition } \\
\hline Digestible protein $(\%)^{\mathrm{b}}$ & 23.00 & 23.00 & 23.00 & 23.00 & 23.00 \\
\hline Crude protein ${ }^{\mathrm{c}}$ & 26.10 & 26.60 & 26.90 & 26.50 & 26.70 \\
\hline Digestible energy $\left(\mathrm{MJ} \mathrm{kg}^{-1}\right)^{\mathrm{b}}$ & 13.38 & 13.38 & 13.38 & 13.38 & 13.38 \\
\hline Ether extract $(\%)^{\mathrm{c}}$ & 2.20 & 2.75 & 2.32 & 2.87 & 3.15 \\
\hline Crude fiber $(\%)^{\mathrm{c}}$ & 3.92 & 3.86 & 4.07 & 3.67 & 3.62 \\
\hline Lysine $(\%)^{\mathrm{b}}$ & 1.64 & 1.64 & 1.64 & 1.64 & 1.64 \\
\hline Methionine $(\%)^{\mathrm{b}}$ & 0.38 & 0.38 & 0.38 & 0.38 & 0.38 \\
\hline Threonine $(\%)^{\mathrm{b}}$ & 0.83 & 0.83 & 0.83 & 0.83 & 0.83 \\
\hline Calcium $(\%)^{\mathrm{b}}$ & 1.05 & 1.05 & 1.05 & 1.05 & 1.05 \\
\hline Available phosphorus $(\%)^{\mathrm{b}}$ & 0.70 & 0.70 & 0.70 & 0.70 & 0.70 \\
\hline
\end{tabular}

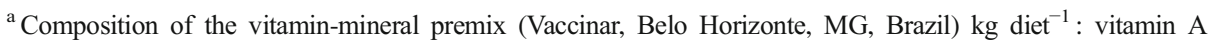
500,000 UI, vitamin D3 250,000 UI, vitamin E $5000 \mathrm{mg}$, vitamin K3 $500 \mathrm{mg}$, vitamin B1 $1.000 \mathrm{mg}$, vitamin B2 $1.000 \mathrm{mg}$, vitamin B6 $1000 \mathrm{mg}$, vitamin B12 $2000 \mathrm{mg}$, niacin 2.500, folic acid $500 \mathrm{mg}$, biotin $10 \mathrm{mg}$, vitamin C $10,000 \mathrm{mg}$, choline $100,000 \mathrm{mg}$, inositol $1000 \mathrm{mg}$, selenium $30 \mathrm{mg}$, iron $5000 \mathrm{mg}$, copper $1000 \mathrm{mg}$, manganese $5000 \mathrm{mg}$, zinc $9000 \mathrm{mg}$, cobalt $50 \mathrm{mg}$, iodine $200 \mathrm{mg}$

${ }^{\mathrm{b}}$ Estimated values based on digestible nutrients determined by Abimorad et al. (2008)

${ }^{\mathrm{c}}$ Analyzed values according to AOAC (2000) 
Agroindustrial Ltda, Campinas, SP, Brazil. According to the manufacturer, these polysaccharides were obtained from yeast (S. cerevisiae) cell walls and contained more than $30 \%$ of the total weight was $\beta$-glucans ( $23.9 \%$ of 1.3 and $1.6 \beta$-glucans) and $12 \%$ was MOS. $\beta$-glucans and MOS were included in the diets at levels of $0.0,0.1,0.2,0.4$, and $0.8 \%$ in substitution of corn (Table 1), totalizing five treatments each with four replicates. Diets were dried in a forcedair oven $\left(55^{\circ} \mathrm{C}\right.$ for $24 \mathrm{~h}$ ) (Marconi MA035, Piracicaba, SP Brazil) and stored under refrigeration $\left(5^{\circ} \mathrm{C}\right)$ until use.

\section{Fish, experimental conditions, and feeding}

All experimental protocols were approved by the Committee for Ethics in Animal Experimentation of Universidade Estadual de Mato Grosso do Sul (protocol n ${ }^{\circ}$ 014/2013). Juvenile pacu were obtained from a commercial fish farm, acclimated to the experimental system, and fed the control diet (with no $\beta$-glucans and MOS) for 1 week. After this period, 160 fish were anesthetized with benzocaine $\left(100 \mathrm{mg} \mathrm{L}^{-1}\right)$, weighed individually $(30.93 \pm 0.46 \mathrm{~g}$ ), and randomly distributed in 20 aquaria $(300 \mathrm{~L})$ which had a laboratory water recirculation system (4 $\mathrm{L} \mathrm{min}^{-1}$ per aquarium) including individual valve control, a physical and biological filter $(1500 \mathrm{~L})$, a digitally controlled temperature, electrical resistance $(5000 \mathrm{~W})$, and supplementary aeration $(746 \mathrm{~W})$. The total water volume of the recirculation system was $4800 \mathrm{~L}$ and the replacement rate was $80 \%$ per hour. Fish were hand-fed until apparent satiation at 08:00, 11:00, 13:00, and 16:30 for 30 days. Diets were weighted daily prior to the first and after the last feeding to calculate the amount of diet consumed.

At the end of trial, all fish were weighed individually to calculate the following parameters: weight gain $(\mathrm{WG})=$ (final body weight $(\mathrm{g})$ - initial body weight $(\mathrm{g})$ ); feed conversion ratio $(\mathrm{FCR})=$ feed intake $(\mathrm{g}) / \mathrm{WG}(\mathrm{g})$; specific growth rate (SGR, \% day $\left.^{-1}\right)=100 \times(\ln$ final weight $(\mathrm{g})-\ln$ initial weight $(\mathrm{g}) /$ days of the trial $)$; protein efficiency ratio $(\mathrm{PER})=\mathrm{WG}(\mathrm{g}) /$ protein intake $(\mathrm{g})$.

Dissolved oxygen $\left(6.21 \pm 0.54 \mathrm{mg} \mathrm{L}^{-1}\right)$, temperature $\left(26.20 \pm 0.32{ }^{\circ} \mathrm{C}\right)$, and $\mathrm{pH}$ $(7.11 \pm 0.21)$ were measured daily, prior to the first feeding (08:00), using a multiparameter (U-50, Horiba, Minami-ku, Kyoto, Japan). Total ammonia $\left(0.02 \pm 0.01 \mathrm{mg} \mathrm{L}^{-1}\right)$ was measured weekly using a commercial kit (Hach, Loveland, CO, USA). All water quality parameters were measured in one aquarium per treatment of the water recirculation system.

Cleaning management was periodically realized by siphoning and renewing $20 \%$ of the total volume of the system. The values of the water quality parameters found in this study were considered adequate for pacu (Castagnolli and Zuim 1985).

\section{Hematological procedures}

At the end of the growth trial and after $24 \mathrm{~h}$ fasting, three fish per aquarium, 12 fish per treatment $(n=60)$ were anesthetized with benzocaine $\left(100 \mathrm{mg} \mathrm{L}^{-1}\right)$ for weighing and blood collection. The blood samples were collected by caudal puncture using a syringe containing EDTA $(3 \%)$, and the blood was placed in polypropylene tubes $(1.5 \mathrm{~mL})$ that were maintained between 5 and $7{ }^{\circ} \mathrm{C}$ until processing. The percentage of hematocrit was determined by the microhematocrit method (Goldenfarb et al. 1971), and samples were processed in a microhematocrit-centrifuge (NI 1807 Nova Instruments, Piracicaba, SP, Brazil) for $5 \mathrm{~min}$ and 10,000 rpm. Hemoglobin was determined using the cyanomethemoglobin method (Gold Analisa Diagnóstica, Minas Gerais, Brazil), and erythrocyte counting was conducted after 
blood dilution (1:200) in formalin-citrate solution using a Neubauer hemocytometer. The MCV and mean corpuscular hemoglobin concentration (MCMC) were also calculated (Wintrobe 1934). Total plasma protein (TPP) was determined by the refractometry method.

\section{Somatic index and histological analyses}

Fish (two per aquarium; eight per treatment; $n=40$ ) were euthanized with benzocaine (300 $\mathrm{mg} \mathrm{L}^{-1}$ ). The liver and viscera were weighed to determine the hepatosomatic index (HSI) and viscerosomatic index (VSI) which were calculated without liver weight. Crosssection cuts were collected from the medial region of intestine, dissected, and washed with paraformaldehyde (10\%) before being fixed in paraformaldehyde (10\%) for $24 \mathrm{~h}$ at room temperature. After this period, intestine fragments were washed in running water for $12 \mathrm{~h}$ and subsequently immersed in $70 \%$ ethanol until processing. The samples were dehydrated in graded ethanol series, cleaned in xylene, and embedded in paraplast. The intestine was sectioned at $5 \mu \mathrm{m}$ thickness and stained with hematoxylin and eosin (H\&E) for histological analysis. Images were obtained from the H\&E stained sections (Nikon Eclipse E200MV, Infinity 1 Camera) of the intestines, and morphometric measurements were performed using an Image Analysis System (Image J 1.49f software). From each intestine section, two segments were analyzed. The intestinal morphological variables evaluated were villus perimeter, villus height, villus thickness, crypt depth, and villus: crypt ratio according to Pryor et al. (2003), Hisano et al. (2006), and Schwarz et al. (2010). The measurements from each animal were then averaged to estimate a mean value for each variable per treatment (40 measurements per parameter for each treatment).

\section{Statistical analysis}

Percentage data were transformed using arcsine $\sqrt{ } x$. All data were subjected to normality and homogeneity test. If the assumption of normality and homogeneity was met, data were subjected to one-way analysis of variance (ANOVA). Polynomial regression was used to evaluate growth performance. The blood parameters, somatic indices, and intestinal morphometry values were subjected to Tukey's test. A significance level of $P<0.05$ was used. Data are expressed as mean values \pm SD. All statistical analyses were performed using SPSS (version 11.5.).

\section{Results}

During the experimental period, the survival rate was $100 \%$ for all treatments. The growth performance variables are shown in Table 2 . WG showed a quadratic effect $\left(\hat{Y}=-21.144 x^{2}+\right.$ $8.817 x+26.612 ; R^{2}=0.99$, RMSE $\left.=4.67\right)$, with an optimum estimated $\beta$-glucans and MOS level of $0.21 \%$. FCR and PER also showed a quadratic effect with the regression equations $\left(\hat{Y}=0.760 x^{2}-0.310 x+1.770 ; R^{2}=0.48, \mathrm{RMSE}=0.26 ; \hat{Y}=-2.014 x^{2}+0.982 x+2.390 ;\right.$ $R^{2}=0.45, \mathrm{RMSE}=0.41$ ), respectively. Estimated optimum levels of both equations were not considered due to low coefficient of determination of equations. However, the best responses in FCR and PER were observed at 0.1 and $0.2 \%$.

For fish fed 0.1 and $0.2 \% \beta$-glucans and MOS, the villus perimeter of showed the highest values and differed statistically $(P<0.05)$ from the control and $0.8 \%$ treatment; however, it did not differ from the $0.4 \%$ treatment (Table 3 ). The villus height of animals fed the control diet 
Table 2 Initial weight (IW), weight gain (WG), feed conversion ratio (FCR) protein efficiency ratio (PER), and specific growth rate (SGR) of pacu fed diets with graded levels of $\beta$-glucans and MOS (\%)

\begin{tabular}{|c|c|c|c|c|c|}
\hline \multirow[t]{2}{*}{ Parameters } & \multicolumn{5}{|c|}{$\beta$-Glucans and MOS $(\%)$} \\
\hline & 0.0 & 0.1 & 0.2 & 0.4 & 0.8 \\
\hline IW (g) & $30.31 \pm 0.52$ & $31.57 \pm 2.05$ & $30.85 \pm 2.34$ & $31.11 \pm 0.82$ & $30.79 \pm 3.32$ \\
\hline WG (g) & $23.28 \pm 1.65$ & $30.73 \pm 1.48$ & $30.40 \pm 4.35$ & $23.10 \pm 5.35$ & $20.82 \pm 3.08$ \\
\hline $\mathrm{FCR}^{1}$ & $1.80 \pm 0.09$ & $1.47 \pm 0.08$ & $1.38 \pm 0.20$ & $1.88 \pm 0.47$ & $2.00 \pm 0.28$ \\
\hline PER & $2.14 \pm 0.11$ & $2.62 \pm 0.14$ & $2.82 \pm 0.43$ & $2.14 \pm 0.46$ & $1.95 \pm 0.25$ \\
\hline SGR $\left(\%\right.$ day $\left.^{-1}\right)$ & $3.83 \pm 0.09$ & $3.99 \pm 0.09$ & $3.87 \pm 0.07$ & $3.79 \pm 0.22$ & $3.78 \pm 0.11$ \\
\hline
\end{tabular}

Values are expressed by mean $\pm \mathrm{SD}$ of four replicates (aquarium), means of eight fish per aquarium. Quadratic effect: WG $\left(\hat{Y}=-21.144 x^{2}+8.817 x+26.61 ; R^{2}=0.99 ; \operatorname{RMSE}=4.67\right) ; \operatorname{FCR}\left(\hat{Y}=0.760 x^{2}+0.310 x+1.77\right.$; $\left.R^{2}=0.48 ; \operatorname{RMSE}=0.26\right) ; \operatorname{PER}\left(\hat{Y}=-2.014 x^{2}+0.982 x+2.39 ; R^{2}=0.45 ; \operatorname{RMSE}=0.41\right)$

was inferior $(P<0.05)$ compared to the other treatments. Pacu fed diets with $0.4 \% \beta$-glucans and MOS exhibited the highest villus thickness and differed $(P<0.05)$ from the 0.2 and $0.8 \%$ treatments (Table 4). No differences in the crypt depth and the villus:crypt ratio were observed $(P>0.05)$ among treatments.

The HSI, VSI, hematocrit, hemoglobin, MCV, and MCHC did not show any differences $(P>0.05)$ among different treatments (Table 4). On the other hand, pacu fed a diet containing 0.2 and $0.4 \% \beta$-glucans and MOS exhibited the highest values of red blood cells (RBC) and statistically $(P<0.05)$ differed from the $0.8 \%$ and control treatments (Table 4$)$. The total plasmatic protein (TPP) of juvenile pacu fed diets containing $0.4 \% \beta$-glucans and MOS had the highest value but was similar to the 0.1 and $0.2 \%$ treatments; however, it differed $(P<0.05)$ from the control and $0.8 \%$ treatment.

\section{Discussion}

The results of the present study indicate that pacu fed with 0.1 and $0.2 \% \beta$-glucans and MOS exhibited best growth and feed efficiency responses. These results agree with those that evaluated primarily $\beta$-glucans and MOS (in association) from yeast cell walls at similar dietary levels for Nile tilapia fed $0.3 \%$ yeast cell wall (Hisano et al. 2007) and fed $0.3 \% \beta$ glucans and MOS (Selim and Reda 2015). On the other hand, supplementation with $\beta$-glucans or MOS individually did not have a positive effect on the growth performance parameters for tambaqui Colossoma macropomum fed increased levels of $\beta$-glucans (Chagas et al. 2013), Nile tilapia fed $0.1-0.2 \% \beta$-glucans (Whittington et al. 2005), tilapia and pacu fed increased levels of MOS (Sado et al. 2008, 2014a), and gilthead sea bream fed 0.2-0.4\% MOS (Dimitroglou et al. 2010). The contradictory results among the different studies using $\beta$ glucans or MOS either isolated or in combination could be related to the different fish species, developmental stage (Pryor et al. 2003), feed period, dietary levels, different commercial products, and experimental conditions.

The direct mechanism of dietary $\beta$-glucans and MOS on growth performance is not totally clear. $\beta$-glucans induce an intestinal immune response that contributed to an improved resistance against pathogens and in consequence, improved growth (Kühlwein et al. 2014). MOS has a proven prebiotic effect and its principal role of action is through the modulation of intestinal microbiota by promoting the growth of lactic acid bacteria in the intestine, thus 


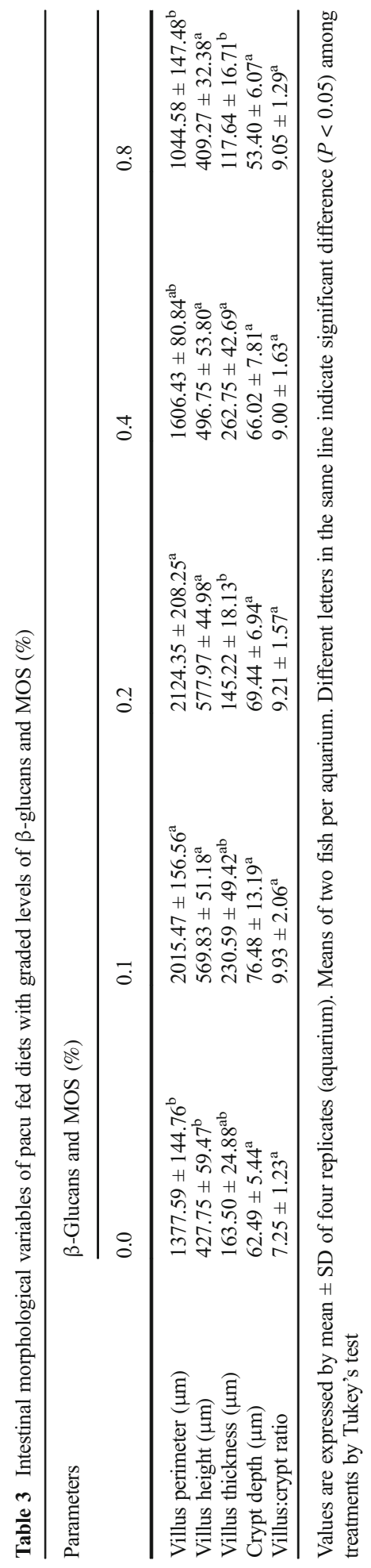


Table 4 Hepatosomatic index (HSI), viscerosomatic index (VSI), hematocrit (Htc), hemoglobin (Hb), red blood cell $(\mathrm{RBC})$, mean corpuscular volume (MCV), mean corpuscular hemoglobin concentration (MCHC), and total plasma protein (TPP) of pacu fed diets with graded levels of $\beta$-glucans and MOS (\%)

\begin{tabular}{|c|c|c|c|c|c|}
\hline \multirow[t]{2}{*}{ Parameters } & \multicolumn{5}{|c|}{$\beta$-Glucans and $\operatorname{MOS}(\%)$} \\
\hline & 0.0 & 0.1 & 0.2 & 0.4 & 0.8 \\
\hline HSI (\%) & $1.15 \pm 0.52^{\mathrm{a}}$ & $1.12 \pm 0.35^{\mathrm{a}}$ & $1.11 \pm 0.21^{\mathrm{a}}$ & $1.13 \pm 0.38^{\mathrm{a}}$ & $1.12 \pm 0.30^{\mathrm{a}}$ \\
\hline VSI (\%) & $4.67 \pm 0.90^{\mathrm{a}}$ & $4.87 \pm 1.39^{\mathrm{a}}$ & $4.52 \pm 0.88^{\mathrm{a}}$ & $4.65 \pm 1.66^{\mathrm{a}}$ & $4.55 \pm 0.86^{\mathrm{a}}$ \\
\hline Htc $(\%)$ & $32.13 \pm 1.57^{\mathrm{a}}$ & $33.75 \pm 1.03^{\mathrm{a}}$ & $35.13 \pm 0.95^{\mathrm{a}}$ & $34.25 \pm 1.33^{\mathrm{a}}$ & $31.00 \pm 1.31^{\mathrm{a}}$ \\
\hline $\mathrm{Hb}\left(\mathrm{g} \mathrm{dL}^{-1}\right)$ & $11.73 \pm 0.89^{\mathrm{a}}$ & $10.04 \pm 0.60^{\mathrm{a}}$ & $11.07 \pm 0.54^{\mathrm{a}}$ & $9.99 \pm 0.73^{\mathrm{a}}$ & $10.75 \pm 0.65^{\mathrm{a}}$ \\
\hline $\operatorname{RBC}\left(\times 10^{6} \mu \mathrm{L}^{-1}\right)$ & $1.74 \pm 0.14^{\mathrm{b}}$ & $2.28 \pm 0.10^{\mathrm{ab}}$ & $2.50 \pm 0.13^{\mathrm{a}}$ & $2.46 \pm 0.14^{\mathrm{a}}$ & $1.76 \pm 0.15^{\mathrm{b}}$ \\
\hline MCV (fL) & $154.00 \pm 9.38^{\mathrm{a}}$ & $149.76 \pm 6.43^{\mathrm{a}}$ & $142.74 \pm 6.56^{\mathrm{a}}$ & $141.53 \pm 8.07^{\mathrm{a}}$ & $190.67 \pm 27.08^{a}$ \\
\hline $\mathrm{MCHC}\left(\mathrm{g} \mathrm{dL}^{-1}\right)$ & $36.37 \pm 1.90^{\mathrm{a}}$ & $29.86 \pm 1.76^{\mathrm{a}}$ & $31.62 \pm 1.69^{\mathrm{a}}$ & $29.89 \pm 1.88^{\mathrm{a}}$ & $34.55 \pm 1.02^{\mathrm{a}}$ \\
\hline $\mathrm{TPP}\left(\mathrm{mg} \mathrm{dL}^{-1}\right)$ & $3.68 \pm 0.15^{\mathrm{b}}$ & $4.09 \pm 0.12^{\mathrm{ab}}$ & $4.15 \pm 13^{\mathrm{ab}}$ & $4.26 \pm 0.15^{\mathrm{a}}$ & $3.66 \pm 0.15^{\mathrm{b}}$ \\
\hline
\end{tabular}

Values are expressed by mean $\pm \mathrm{SD}$ of four replicates (aquarium). Means of three fish per aquarium. Different letters in the same line indicate significant difference $(P<0.05)$ among treatments by Tukey's test

decreasing the colonization of pathogenic bacteria (Andrews et al. 2009). It is feasible that the association of $\beta$-glucans and MOS enhanced these positive effects and contributed to improved growth performance and feed efficiency of pacu fed 0.1 and $0.2 \% \beta$-glucans and MOS.

Dietary combined $\beta$-glucans and MOS at levels of 0.1 and $0.2 \%$ positively affected $(P<0.05)$ the villus height and perimeter of pacu. Similar results were observed in channel catfish Ictalurus punctatus fed diets $0.2 \%$ ( $\beta-1.3 / 1.6$-glucans and MOS) on improvement in the villus height (Zhu et al. 2012), Nile tilapia fed $0.1 \%$ of yeast cell wall (primarily $\beta$-glucans and MOS) resulting in enhancement of villus perimeter (Hisano et al. 2006), and fed $0.3 \%$ of $\beta$-glucans and MOS with improvement in intestinal villus height and microvillus density (Selim and Reda 2015). On the other hand, no differences in intestinal morphology were observed for pacu fed graded levels of MOS (Sado et al. 2014a) and Gulf of Mexico sturgeon Acipenser oxyrinchus desotoi fed 0.3\% MOS (Pryor et al. 2003).

According to Zhu et al. (2012), the intestine plays an important role in nutrient digestion and absorption, and digestive function correlates with intestinal developments that can improve intestine surface area for nutrient absorption by increasing the intestinal villus height. Furthermore, the improvement in apparent digestibility coefficient (ADC) for dry matter was observed for Nile tilapia fed $0.3 \%$ of dietary yeast cell wall (primarily $\beta$-glucans and MOS) (Hisano et al. 2008) and for red drum Sciaenops ocellatus fed $0.1 \%$ of MOS for ADC of protein and energy (Zhou et al. 2010). Thus, the positive correlation of enhancement in villus height and perimeter with nutrient uptake also explain the best responses on growth and feed efficiency for pacu fed 0.1 and $0.2 \%$ of $\beta$-glucans and MOS.

In the present study, the HSI and VSI showed no difference $(P>0.05)$ among all treatments. Similar observations were reported by Genc et al. (2007) for hybrid tilapia (O. niloticus $\times O$. aureus) fed increased levels of MOS. In contrast, Dimitroglou et al. (2010) observed that fish fed diets with $0.2-0.4 \%$ MOS in fish meal based diet exhibited a lower HSI; however, histological examination appeared not affect hepatocyte glycogen deposition. According to Jobling (2001), changes in energy reserves can be determined through these indices, which may indicate the energy balance in fish, as energy reserves in fish can be in the liver, muscle, and viscera fat. No differences in these indices were expected, since the diets were formulated to be isonitrogenous and isocaloric. 
A few studies have investigated the effects of dietary $\beta$-glucans and MOS on hematological parameters. The hematocrit, hemoglobin, and hematimetric indices as well as the MCV and MCHC did not show differences $(P>0.05)$ among treatments. In accordance with the present study, Sado et al. (2008) also did not observe differences in the hematological parameters of Nile tilapia fed 0, 0.2,0.4, 0.6, 0.8, and 1\% MOS and neither did Welker et al. (2007) for channel catfish fed diets containing 2.0\% MOS. On the other hand, the RBC count and TPP concentration showed statistical significant differences. Similarly, Sado et al. (2014b) reported that RBC and TPP of pacu were significantly affected by graded MOS levels. According to the same authors, an increase in TPP can indicate better immunological status, since lysozyme and complement factors represent a fraction of TPP. Although some variations were observed, all blood parameters analyzed in this study were within the normal range reported for juvenile pacu in a semi-intensive fish culture system (Tavares-Dias and Mataqueiro 2004).

Research evaluating a combination of dietary yeast polysaccharides ( $\beta$-glucans and MOS) is still scarce. Supplementation with both polysaccharides in pacu diets boosted the responses for growth, feed efficiency, and intestinal morphology, indicating a synergic effect in pacu. However, more research is necessary to elucidate the associated and isolated effect of $\beta$ glucans and MOS in several fish species. Dietary supplementation with $0.2 \% \beta$-glucans and MOS for 30 days promoted better growth responses, feed efficiency, and intestinal morphology, with no detrimental effects on hematological parameters for juvenile pacu.

Acknowledgments The authors would like to thank YesSinergy do Brasil Agroindustrial Ltda for financial support and Piscicultura Polettini for fish donation. We also thank the students Victor R. Pinheiro and Giovanni H. Ferri for their support and assistance during the experimental trial.

\section{References}

Abimorad EG, Squassoni GH, Carneiro DJ (2008) Apparent digestibility of protein, energy, and amino acids in some selected feed ingredients for pacu Piaractus mesopotamicus. Aquac Nutr 14:374-380

Andrews SR, Sahu NP, Pal AK, Kumar S (2009) Haematological modulation and growth of Labeo rohita fingerlings: effect of dietary mannan oligosaccharide, yeast extract, protein hydrolysate and chlorella. Aquac Res 41:61-69

AOAC (2000) Official methods of analysis of the association of analytical chemists. Association of Official Analytical Chemists, International 17th edition, Gaithersburg, MD, USA

Castagnolli N, Zuim SMF (1985) Consolidação do conhecimento adquirido sobre o pacu Colossoma mitrei (Berg, 1895). FCAV/UNESP, Jaboticabal

Chagas EC, Pilarski F, Sakabe R, De Moraes FR (2013) Desempenho produtivo e respostas fisiopatológicas de tambaquis alimentados com ração suplementada com $\beta$ - glucano. Pesq Agropec Bras 48(8):899-905

Dimitroglou A, Merrifield DL, Moate R, Davies SJ, Spring P, Sweetman J, Bradley G (2009) Dietary mannan oligosaccharide supplementation modulates intestinal microbial ecology and improves gut morphology of rainbow trout, Oncorhynchus mykiss (Walbaum). J Anim Sci 87(10):3226-3234

Dimitroglou A, Merrifield DL, Spring P, Sweetman J, Moate R, Davies SJ (2010) Effects of mannan oligosaccharide (MOS) supplementation on growth performance, feed utilisation, intestinal histology and gut microbiota of gilthead sea bream (Sparus aurata). Aquaculture 300:182-188

Engstad RE (1993) Recognition of yeast cell wall glucan by Atlantic salmon (Salmo salar L.) macrophages. Dev Comp Immunol 17(4):319-330

FAO (Food and Agriculture Organization) (2016) The state of world fisheries and aquaculture. Rome

Genc MA, Yilmaz E, Genc E, Aktas M (2007) Effects of dietary mannan oligosaccharides (MOS) on growth, body composition, and intestine and liver histology of the hybrid tilapia (Oreochromis niloticus x O. aureus). Isr J Aquacult Bamidgeh 59(1):10-16

Goldenfarb PB, Bowyer FP, Hall E, Brosious E (1971) Reproducibility in the hematology laboratory: the microhematocrit determinations. Am J Clin Pathol 56(1):35-39 
Gopalakannan A, Arul V (2010) Enhancement of the innate immune system and disease-resistant activity in Cyprinus carpio by oral administration of $\beta$-glucan and whole cell yeast. Aquac Res 41:884-892

Hisano H, Silva MDP, Barros MM, Pezzato LE (2006) Levedura íntegra e derivados do seu processamento em rações para tilápia do Nilo: aspectos hematológicos e histológicos. Acta Sci Biol Sci 28(4):311-318

Hisano H, Narvaez-Solarte WV, Barros MM, Pezzato LE (2007) Desempenho produtivo de alevinos de tilápiado-nilo alimentados com levedura e derivados. Pesq Agropec Bras 42(7):1035-1042

Hisano H, Sampaio FG, Barros MM, Pezzato LE (2008) Digestibilidade aparente de rações contendo levedura íntegra, levedura autolisada e parede celular pela tilápia do Nilo. Bol Inst Pesca 34(2):281-287

Hough JS (1990) Biotecnología de la cerveza y de malta. Ed. Acribia, Zaragoza

Instituto Brasileiro de Geografia e Estatística - IBGE (2015) Produção da Pecuária Municipal. Rio de Janeiro, RJ, Brazil Jobling M (2001) Nutrient partitioning and the influence of feed composition on body composition. In: Houlihan D, Boujard T, Jobling M (eds) Food intake in fish. Blackwell Science, Oxford, pp 354-375

Kühlwein H, Merrifield DL, Rawling MD, Foey AD, Davies SJ (2014) Effects of dietary $\beta$-(1,3)(1,6)-D-glucan supplementation on growth performance, intestinal morphology and haemato-immunological profile of mirror carp (Cyprinus carpio L.) J Anim Physiol Anim Nutr 98(2):279-289

Li P, Gatlin DM (2003) Evaluation of brewers yeast (Saccharomyces cerevisiae) as feed supplement for hybrid striped bass (Morone chrysops $\times$ M. saxatilis). Aquaculture 219:681-692

Li P, Gatlin DM (2004) Dietary brewers yeast and the prebiotic Grobiotic ${ }^{\mathrm{TM}}$ AE influence growth performance, immune responses and resistance of hybrid striped bass (Morone chrysops $\times$ M. saxatilis) to Streptococcus iniae infection. Aquaculture 231:445-456

Ortuño J, Cuesta A, Rodríguez A, Esteban MA, Meseguer J (2002) Oral administration of yeast, Saccharomyces cerevisiae, enhances the cellular innate immune response of gilthead seabream (Sparus aurata L.) Vet Immunol Immunopathol 85:41-50

Patel S, Goyal A (2012) The current trends and future perspectives of prebiotics research: a review. 3. Biotech 2(2):115-125

Paulsen SM, Engstad RE, Robertsen B (2001) Enhanced lysozyme production in Atlantic salmon (Salmo salar L.) macrophages treated with yeast $\beta$-glucan and bacterial lipopolysaccharide. Fish Shellfish Immunol 11(1):23-37

Pryor GS, Royes JB, Chapman FA, Miles RD (2003) Mannan oligosaccharides in fish nutrition: effects of dietary supplementation on growth and gastrointestinal villi structure in Gulf of Mexico sturgeon. N Am J Aquac 65:106-111

Ringø E, Olsen RE, Gifstad TØ, Dalmo RA, Amlund H, Hemre G-I, Bakke AM (2010) Prebiotics in aquaculture: a review. Aquac Nutr 16:117-136

Sado RY, Bicudo AJDA, Cyrino JEP (2008) Feeding dietary mannan oligosaccharides to juvenile Nile tilapia, Oreochromis niloticus, has no effect on hematological parameters and showed decreased feed consumption. J World Aquacult Soc 39:821-826

Sado RY, Bicudo AJDA, Cyrino JEP (2014a) Growth and intestinal morphology of juvenile pacu Piaractus mesopotamicus (Holmberg 1887) fed dietary prebiotics (mannanoligosaccharides-MOS). An Acad Bras Cienc 86(3):1517-1524

Sado RY, Bicudo AJDA, Cyrino JEP (2014b) Hematology of juvenile pacu, Piaractus mesopotamicus (Holmberg, 1887) fed graded levels of mannan oligosaccharides (MOS). Lat Am J Aquat Res 42(1):30-39

Schwarz KS, Furuya WM, Natali MRM, Michelato M, Gualdezi MC (2010) Mananoligossacarídeo em dietas para juvenis de tilapia do Nilo. Acta Sci Anim Sci 32(2):197-203

Secombes CJ, Fletcher TC (1992) The role of phagocytes in protective mechanism of fish. Annu Rev Fish Dis 2:53-71

Selim KM, Reda RM (2015) Beta-glucans and mannan oligosaccharides enhance growth and immunity in Nile tilapia. N Am J Aquac 77(1):22-30

Shrimpton JM, Zydlewski JD, McCormick SD (2001) The stress response of juvenile American shad to handling and confinement is greater during migration in freshwater than in seawater. Trans Am Fish Soc 130(6):1203-1210

Signor A, Pezzato LE, Padilha PM, Padovani CR, Barros MM (2010) Growth performance and metabolic response of Nile tilapia fed rations supplemented with autolized yeast and zinc. Rev Bras Zootec 39(12): $2560-2568$

Song SK, Beck BR, Kim D, Park J, Kim J, Kim HD, Ringø E (2014) Prebiotics as immunostimulants in aquaculture: a review. Fish Shellfish Immunol 40(1):40-48

Staykov Y, Spring P, Denev S, Sweetman J (2007) Effect of a mannan oligosaccharide on the growth performance and immune status of rainbow trout (Oncorhynchus mykiss). Aquac Int 15(2):153-161

Tavares-Dias M, Mataqueiro MI (2004) Características hematológicas, bioquímicas e biométricas de Piaractus mesopotamicus Holmberg, 1887 (Osteichthyes: Characidae) oriundos de cultivo intensivo. Acta Sci Anim Sci 26(2):157-162

Torrecillas S, Makol A, Caballero RJ, Montero D, Robaina L, Real F, Sweetman J, Tort L, Izquierdo MS (2007) Immune stimulation and improved infection resistance in European sea bass (Dicentrarchus labrax) fed mannan oligosaccharides. Fish Shellfish Immunol 23(5):969-981 
Watanabe AL, Viegas EMM, Goncalves LU (2010) Levels of yeast and its by-products on pacu juveniles feeding. Rev Bras Zootec 39(3):447-453

Welker TL, Lim C, Yildirim-Aksoy M, Shelby R, Klesius PH (2007) Immune response and resistance to stress and Edwardsiella ictaluri challenge in channel catfish, Ictalurus punctatus, fed diets containing commercial whole-cell yeast or yeast subcomponents. J World Aquacult Soc 38:24-35

Whittington R, Lim C, Klesius PH (2005) Effect of dietary $\beta$-glucan levels on the growth response and efficacy of Streptococcus iniae vaccine in Nile tilapia, Oreochromis niloticus. Aquaculture 248:217-225

Wintrobe MM (1934) Variations in the size and hemoglobin content of erythrocytes in the blood of various vertebrates. Folia Haematol 51:32-49

Zhou QC, Buentello JA, Gatlin DM (2010) Effects of dietary prebiotics on growth performance, immune response and intestinal morphology of red drum (Sciaenops ocellatus). Aquaculture 309:253-257

Zhu H, Liu H, Yan J, Wang R, Liu L (2012) Effect of yeast polysaccharide on some hematologic parameter and gut morphology in channel catfish (Ictalurus punctatus). Fish Physiol Biochem 38(5):1441-1447 